TAO, Vol. 11, No. 3, 643-660, September 2000

\title{
Three-Dimensional Crustal Structure Around the Source Area of the 1999 Chi-Chi Earthquake in Taiwan and Its Relation to the Aftershock Locations
}

\author{
Win-Bin Cheng ${ }^{1, *}$
}

(Manuscript received 30 March 2000, in final form 10 June 2000)

\begin{abstract}
The Chi-Chi earthquake in Taiwan ( $M_{L}=7.3$ ) occurred on 21 September, 1999 and caused widespread damage over a large area in central Taiwan. A distinct rupture appeared along the Chelungpu fault, which marks the transition from a sedimentary basin to the thrust terrain of the Western foothills. In order to investigate the sub-surface geometry of the Chelungpu fault and the structural features that may have influenced the distribution of Chi-Chi aftershocks, a three-dimensional P-wave velocity model has been developed. The velocity model was determined by simultaneously inverting 41,347 P-wave arrival times from 2,582 pre-mainshock "background" earthquakes. The most striking feature imaged by the velocity model is the high velocity wedge extending from surface to about a 15 km depth beneath the Western foothills. The Chi-Chi mainshock just occurred in the transition area from the high velocity wedge to a basin-type low velocity material where the sub-surface geometry of the Chelungpu fault is proposed. The model also images an elongated high velocity volume at midcrustal depths beneath the eastern flank of the Central Range. West of the Chelungpu fault, another high velocity volume is found at the similar depths which could be associated with the Peikang basement high. Within these two high velocity volumes, the Western foothills and the Central Range exhibit relatively low velocity in the middle-crust. A possible explanation for the nucleation of the Chi-Chi earthquake, the thrust faulting and deformation in central Taiwan is attributed to the interactions between the three high-low-high velocity volumes in response to regional compression.
\end{abstract}

(Key words: Chi-Chi earthquake, 3-D velocity structure, Seismicity)

\footnotetext{
${ }^{1}$ Department of Visual Communication Design, Jin-Wen Institute of Technology, Taipei County, Taiwan

${ }^{*}$ Corresponding author address: Dr. Win-Bin Cheng, Department of Visual Communication Design, JinWen Institute of Technology, 99 Ann-Chung Road, Hsin-Tein, Taipei County, Taiwan

E-mail: wbin@moon20.oc.ntu.edu.tw
} 


\section{INTRODUCTION}

The 21 September, 1999 Chi-Chi, Taiwan earthquake $\left(M_{L}=7.3\right)$ was the most damaging earthquake to have struck Taiwan since the Hsinchu-Taichung earthquake in 1935. The epicenter of the earthquake was located near the Chi-Chi town in Nantou County, and caused distinctive surface rupture along the Chelungpu fault (Fig. 1). However, their only minor to no fractures were observed in the area east of the Chelungpu fault (Lee et al.1999). The Central Weather Bureau reported that the number of aftershocks is about 13,000 within the first month following the mainshock. Most of the hypocenters were located under the Western foothills, including 5 events with magnitude $M_{L} \geq 6.0$ (Fig. 1 b). Since the Western foothills and the Central Range include many active and upthrusted structures formed under a regional NW-SE compressional stress system between the Eurasian and Philippine Sea plates (Ho 1986; Yu et al.1997), the crustal structure could have certainly influenced the initiation and the spatial distribution of the mainshock and aftershock sequence.

The computational method for three-dimensional (3-D) crustal velocity structures using earthquake sources (e.g., Thurber 1983; Eberhart-Phillips 1990) has provided a powerful tool with which to observe the sub-surface geometry of fault zones and their physical properties. Variations in the material properties of a fault zone may be responsible for variations in seismogenic behavior. A number of researchers have studied the 3-D velocity structure in the source areas of large earthquakes (e.g., Eberhart-Phillips and Michael 1993; Lees and Nicholson 1993; Zhao and Negishi 1998) and several have found that the source areas of some earthquakes exhibit a high Poisson's ratio, and low P-wave velocity (Vp). They have proposed that over-pressured fluids exist in the fault zone (Eberhart-Phillips and Michael 1993; Johnson and McEvilly, 1995; Thurber et al.1997; Zhao, 1998). However, other researchers have pointed out that some earthquakes show higher $\mathrm{Vp}$ and they have suggested that the high velocity volumes represent rigid parts of the fault zone (Eberhart-Phillips 1989; Lees and Nicholson 1993; Zhao and Kanamori.1995).

Previously, several three-dimensional Vp models beneath the Taiwan area have been constructed and discussed using natural earthquake data (Roecker et al. 1987; Chen 1995; Rau and Wu 1995; Ma et al. 1996). They mapped large-scale velocity anomalies under the whole Taiwan area. In those studies, the overall resolution was probably greater than $20 \mathrm{~km}$. In considering such a wavelength resolution, some possible shorter-wavelength variations in velocity structure in the Chi-Chi source area may be improperly smoothed or averaged. For instance, most of the epicenters of the Chi-Chi aftershocks shown in Fig. $1 \mathrm{~b}$ are located within a zone of about $20 \mathrm{~km}$ wide between the Chuchih fault and the Chelungpu fault. Therefore, it is important to obtain a detailed 3-D crustal structure of the relatively small, but highly fractured, source area to investigate whether there are any structural features that may have influenced the location of the Chi-Chi mainshock. Additionally, the combined analysis of structure and seismicity helps to characterize the ruptured area during the mainshock and to understand the sub-surface geomery of the Chelungpu fault. This study determined a 3-D velocity structure of the source area by using a progressive inversion of 2,582 pre-mainshock ìbackgroundî events. The results give a distinct picture of the sub-surface geometry of the Chelungpu fault and indicate a zone of blind thrusts east of the Chelungpu fault. 


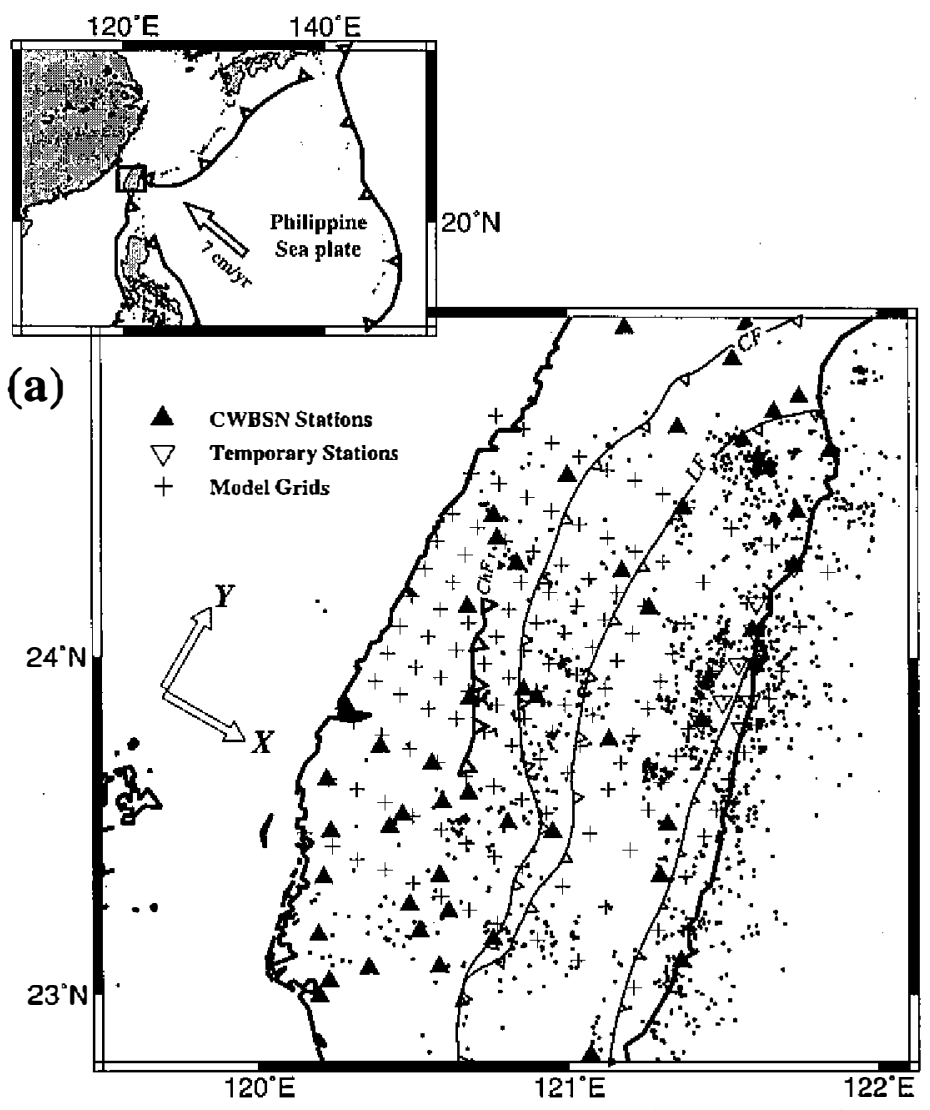

Fig. 1. (a) Map of the central Taiwan region showing the distribution of velocity nodes, "background". earthquakes, a strong motion temporary array and Central Weather Bureau Seismographic Network stations used in the simultaneous inversion. Major thrust faults are also shown with open triangles on the upper side (geodynamic setting in the upper-left). $X$ is positive toward the southeast and $\mathrm{Y}$ is positive toward the northeast. $\mathrm{CF}=$ Chuchih fault; $\mathrm{LF}=$ Lisan fault; $\mathrm{ChF}=$

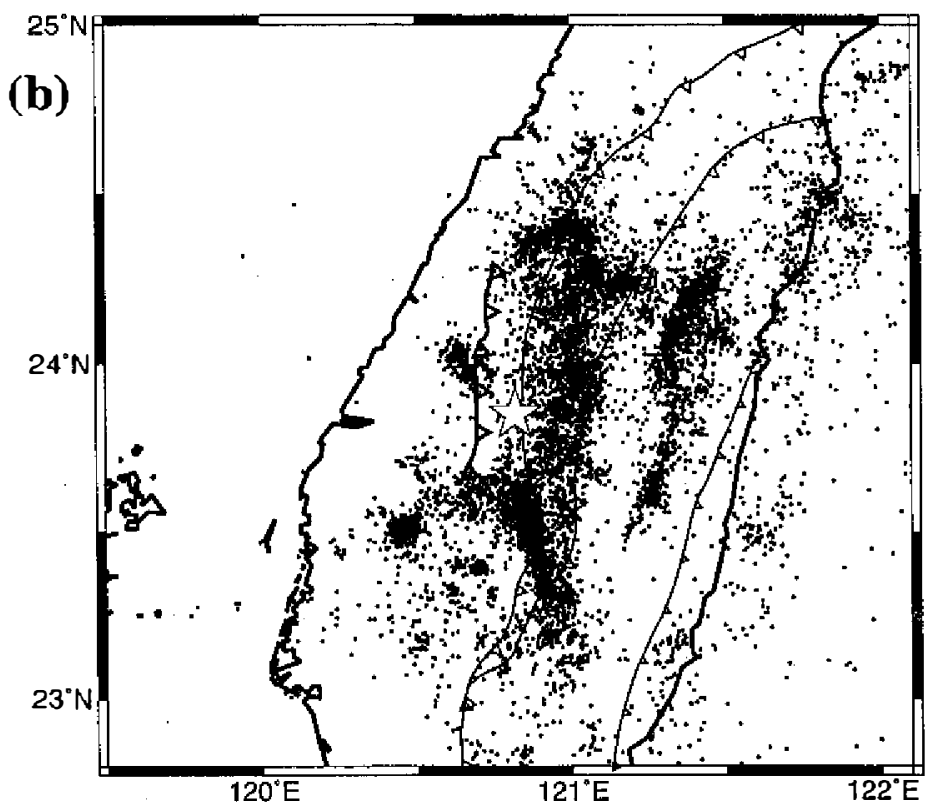
Chelungpu fault. (b) Epicentral distribution of the Chi-Chi aftershock sequence reported by the CWB. Note that most of the aftershocks occurred in a region which was a relatively aseismic zone before the Chi-Chi mainshock. The open star denotes the epicenter of the Chi-Chi mainshock. 


\section{GEOLOGICAL SETTING}

Taiwan has resulted from the active, oblique collision between the Eurasian and Philippine Sea plates (Fig. 1a). Oblique collisions have formed several mountain ranges which can be divided into two geological provinces separated by the Longitudinal Valley. The part west of the Longitudinal Valley consists of metamorphic and sedimentary sequences of the deformed continental margin (Chai 1972; Ho 1982). Between continental margin and the Longitudinal Valley, three geological segments are evident: the Central Range, the Western foothills and the Coastal Plain, from east to west.

The Chuchih Fault is one major upthrust fault that follows the contact between the Central Range slate belt and the fold-and-thrust belt of the Western foothills. The actual fault contact is usually difficult to demonstrate due to heavy vegetation and soil cover on the surface. West of it, the Western foothills, a part of the foreland fold and thrust belt (Ho 1988), are underlain by thick Cenozoic siliciclastic deposits (Chou 1973; Covey 1986; Ho 1986). The Western foothills is a series of hills and mountains whose elevation is less than 1,000 meters above sea level. The rocks are composed of layered Miocene to early Pleistocene sandstone and shale intercalation subjected mainly to Pleistocene orogenic disturbance. East of the Chuchih fault, the main body of Taiwan is divided into the Central Range and the Hs, ehshan Range immediately on its northwest (Fig. 1a), which is composed of a pre-Tertiary metamorphic basement overlain by Paleogene low-grade metamorphosed sediments, Neogene folded and thrusted sedimentary rock layers and Quaternary alluvial deposits (Ho 1986).

The Chelungpu fault could approximately mark a boundary between the Western foothills and the Changhua plain in central Taiwan based on topographical data (Fig. 2a). The ChiChi earthquake in Taiwan caused a large reverse displacement on the Chelungpu fault. Using seismic profiles and the results of paleostress analysis, Lee et al. (1996) investigated the deformation structures and stress regime for the frontal thrusts close to the Chelungpu fault in central Taiwan. However, the deeper part of those thrust faults are still unknown. West of the Chelungpu fault, the Changhua plain, the Coastal plain and the offshore areas are underlain by mostly flat-lying Cenozoic sedimentary sequences that were not deformed by the collision (Sun 1985). A thick sequence of Pleistocene conglomerate was deposited in several places in the western basin, suggesting a sudden uplift on the eastern border at that time (Ho 1986).

\section{DATA AND METHOD}

The earthquake data used in this study were the P- and S-wave arrival times of local earthquakes recorded by the Cen weal Wer Bureau Seismographic Network (CWBSN) before the Chi-Chi mainshock. The CWBSN is equipped with three-component short-period digital seismographs using the velocity-type sensors with adjustable natural frequency of 0.75 to $1.1 \mathrm{~Hz}$ and has real-time operation in the Central Weather Bureau, Taipei (Shin 1993). The events used in this study were selected so as to provide a set of hypocenters of high quality and the best available ray coverage of the study area. Data from 1991 to 1999 were used because they were digital recordings and reliable. Several hundreds of high quality P- and S-arrivals of 
(a)

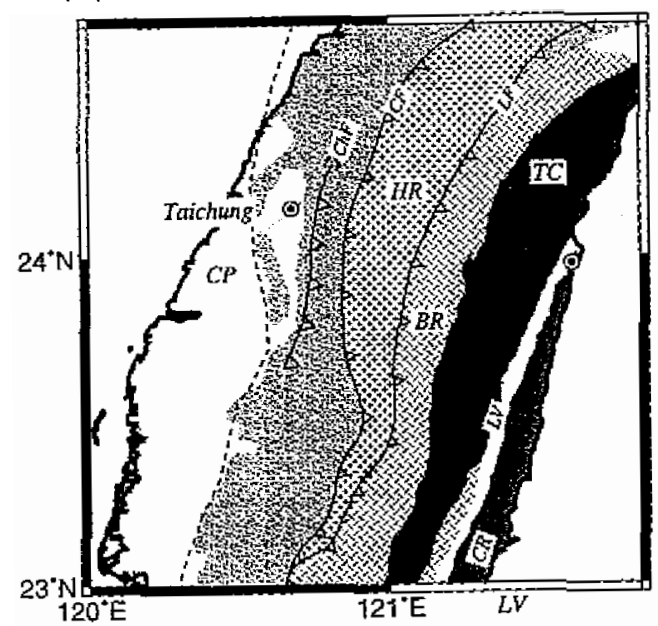

(b)

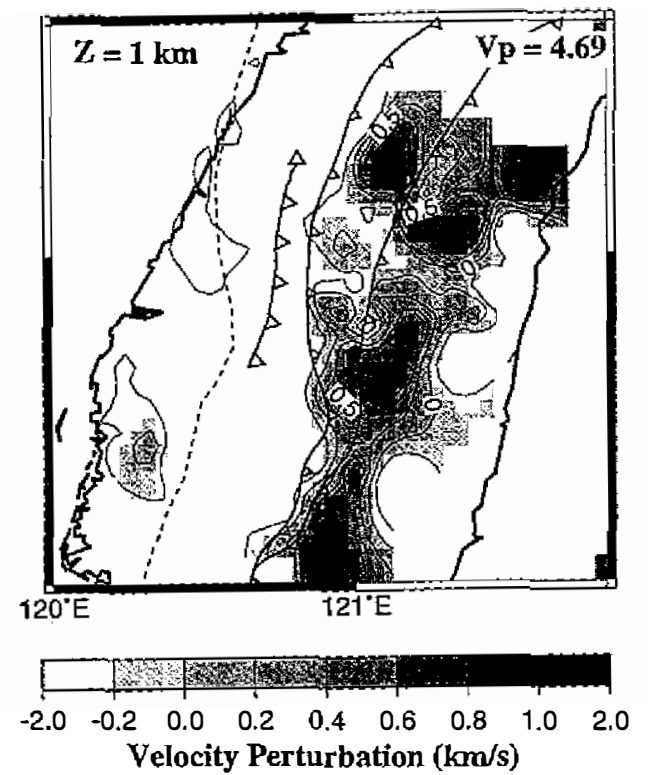

(c)

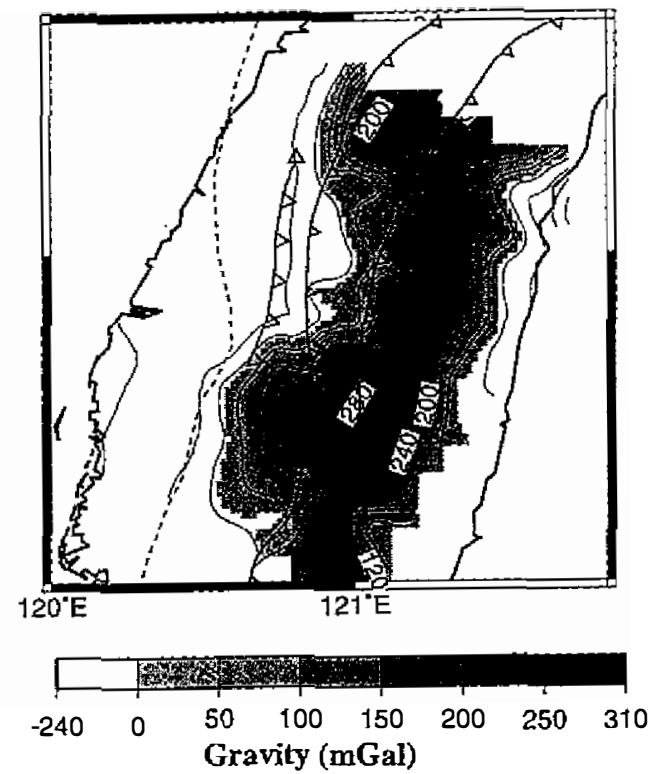

Fig. 2. (a) Simplified surface geology. $\mathrm{CF}=\mathrm{Chuchih}$ fault; $\mathrm{LF}=\mathrm{Lisan}$ fault; $\mathrm{ChF}=\mathrm{Chelungpu}$ fault; $\mathrm{CR}=$ Coastal Range; $\mathrm{HR}=\mathrm{Hs}$, ehshan Range; $\mathrm{BR}=$ Backbone Range; $\mathrm{LV}=$ Longitudinal Valley; $\mathrm{TC}=$ Tananao Complex; $\mathrm{CP}=$ Changhua plain. (b) Map view of the three-dimensional $\mathrm{P}$ velocity model at the depth of $4 \mathrm{~km}$, contour interval $0.5 \mathrm{~km} / \mathrm{s}$. (c) Free-air gravity anomalies within the study area, contour interval 40 mGal (modified from Hsu et al. 1998). 
the acceleration-type recorded by the Taiwan Rapid Earthquake Information Release System (Wu et al. 1997) of the CWB from 1995 to 1998 were also included. Events were restricted to those with at least 12 arrival times (both $\mathrm{P}$ - and S-waves). Furthermore, 110 events recorded by a temporary array deployed in the Hualien area for the periods from 1995 to 1996 are also included in the data set to provide a good coverage of stations for the eastern flank of the Central Range. The travel time data were weighted based on their accuracy as inferred from the signal-to-noise ratio of the seismic signals (weights from 1 to 0.25 for reading errors ranging from $0.01 \mathrm{~s}$ to $0.1 \mathrm{~s}$ for the $\mathrm{P}$-waves). In this study, the total data included 2,582 earthquakes that provide 41,347 P-arrivals and 24,648 S-arrivals.

The tomographic inversion method to derive the central Taiwan three-dimensional velocity model is described by Thurber $(1983,1993)$ and Eberhart-Phillips (1990) and is briefly documented by Evans et al. (1994). The model is parameterized on a grid of nodes as shown in Fig. 1a. Here, we compiled travel-time data for each receiver as a function of the 3-D spatial location of source and inverted them for the 3-D velocity structure. The initial hypocenter locations and origin times of earthquakes as determined by the CWB were used. Ray tracing was done using an approximate 3-D algorithm with curved non-planar ray paths (Um and Thurber 1987). The velocity for a point along a ray path and the velocity partial derivatives were computed by linear interpolation among the surrounding eight grid points. Parameter separation (Pavlis and Booker 1980) operates on the marix of hypocentral and velocity partial derivatives such that hypocentral calculations are separate from velocity calculations. The damped least-squares approach was used to determine velocity in the inversion (Thurber 1983). The initial 1-D velocity model for the study area was modified from Cheng et al. (1999). We performed a trade-off analysis (Eberhart-Phillips 1986) of the data and the model variances in order to select the most suitable damping parameter for use in the damped least-squares inversion.

We measured solution quality by the computing derivative weighted sums for all velocity model nodes. As described in Thurber and Eberhart-Phillips (2000), the derivative weighted sum information is useful in regridding post-processing algorithms for a particular study area. The lower the value of the derivative weighted sum indicates that less or no information is coming from the data, and the velocity solution in the damped least-squares inversion remains close to the initial model.

\section{RESULTS}

Figure 2 a shows the main geological units and near-surface velocity structure obtained within the study area. In general, relatively high velocities in the near-surface velocity model correlate with the Central Range and the Hs, ehshan Range, but low velocities with the Western foothills and Coastal Plain (Fig. 2b). The near surface high and low velocity patterns separated by strong lateral velocity gradients seen in Fig. $2 \mathrm{~b}$ are similar to the pattem of highand low-gravity anomalies seen in the gravity map (Fig. 2c) compiled by Hsu et al. (1998).

The 3-D velocity model is displayed in map views at 1, 4, 9, 13, 17 and $25 \mathrm{~km}$ depths in Fig. 3. As shown in Fig. 4, the resolution is good for the Chi-Chi, Taiwan earthquake seismogenic 

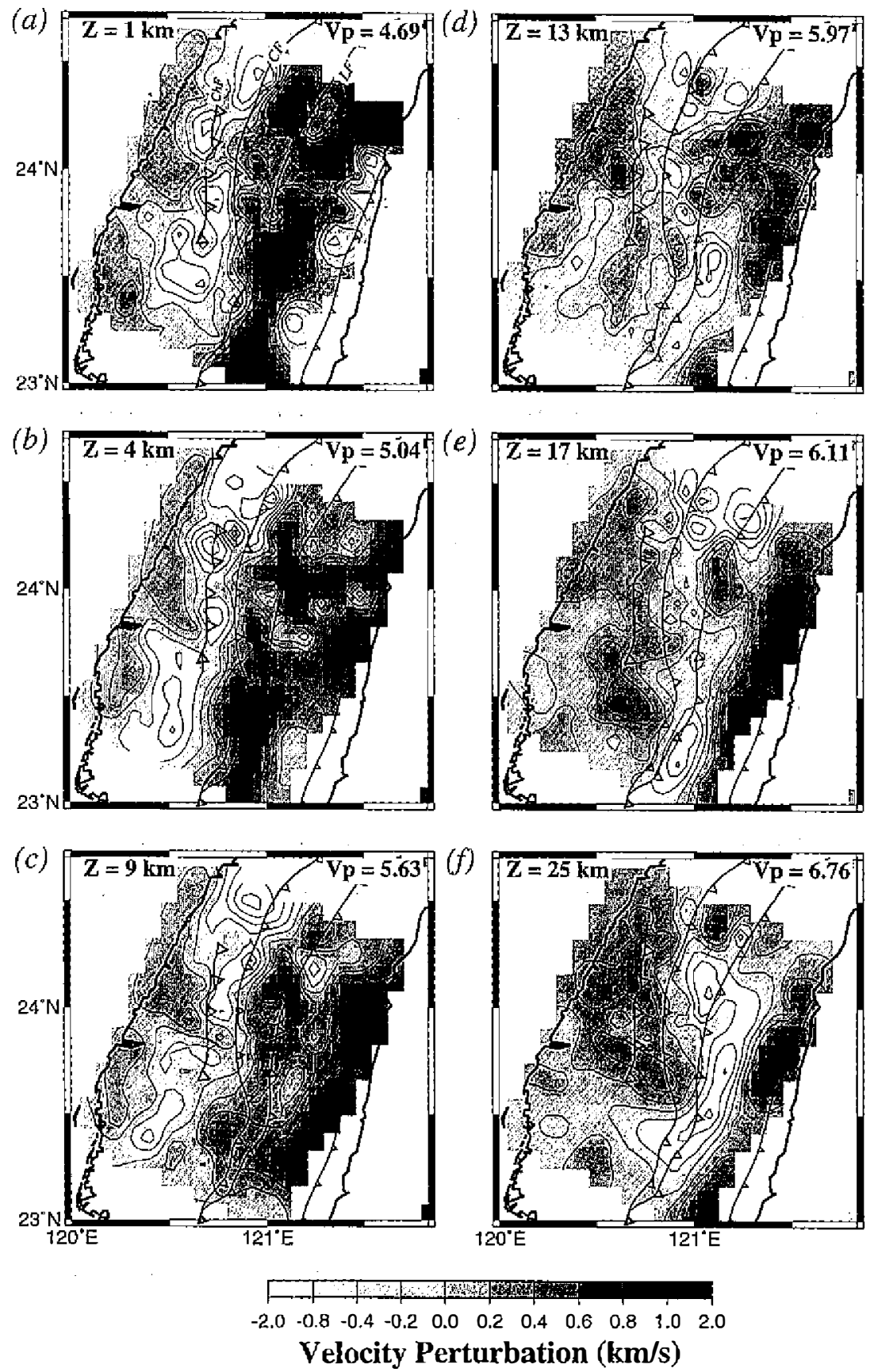

Fig. 3. Results of the three-dimensional $\mathrm{P}$ velocity model shown in map-view at depths of (a) $1 \mathrm{~km}$; (b) $4 \mathrm{~km}$; (c) $9 \mathrm{~km}$; (d) $13 \mathrm{~km}$; (e) $17 \mathrm{~km}$; and (f) 25 $\mathrm{km}$. Contour interval is $0.2 \mathrm{~km} / \mathrm{s}$. See Fig. 1 for map orientation. $\mathrm{CF}=$ Chuchih fault; $\mathrm{LF}=$ Lisan fault; $\mathrm{ChF}=$ Chelungpu fault. 


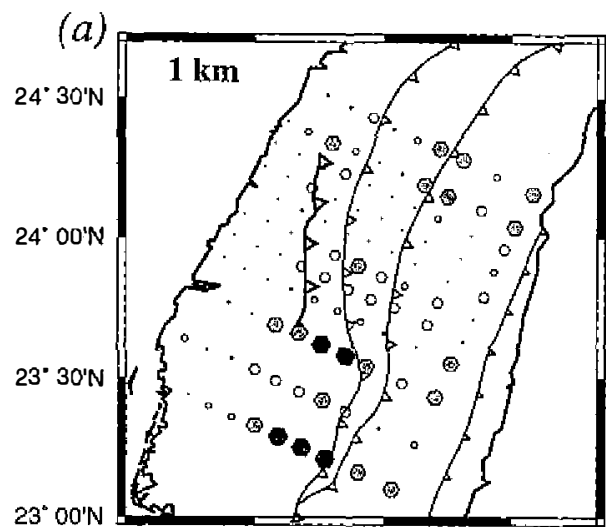

(d)
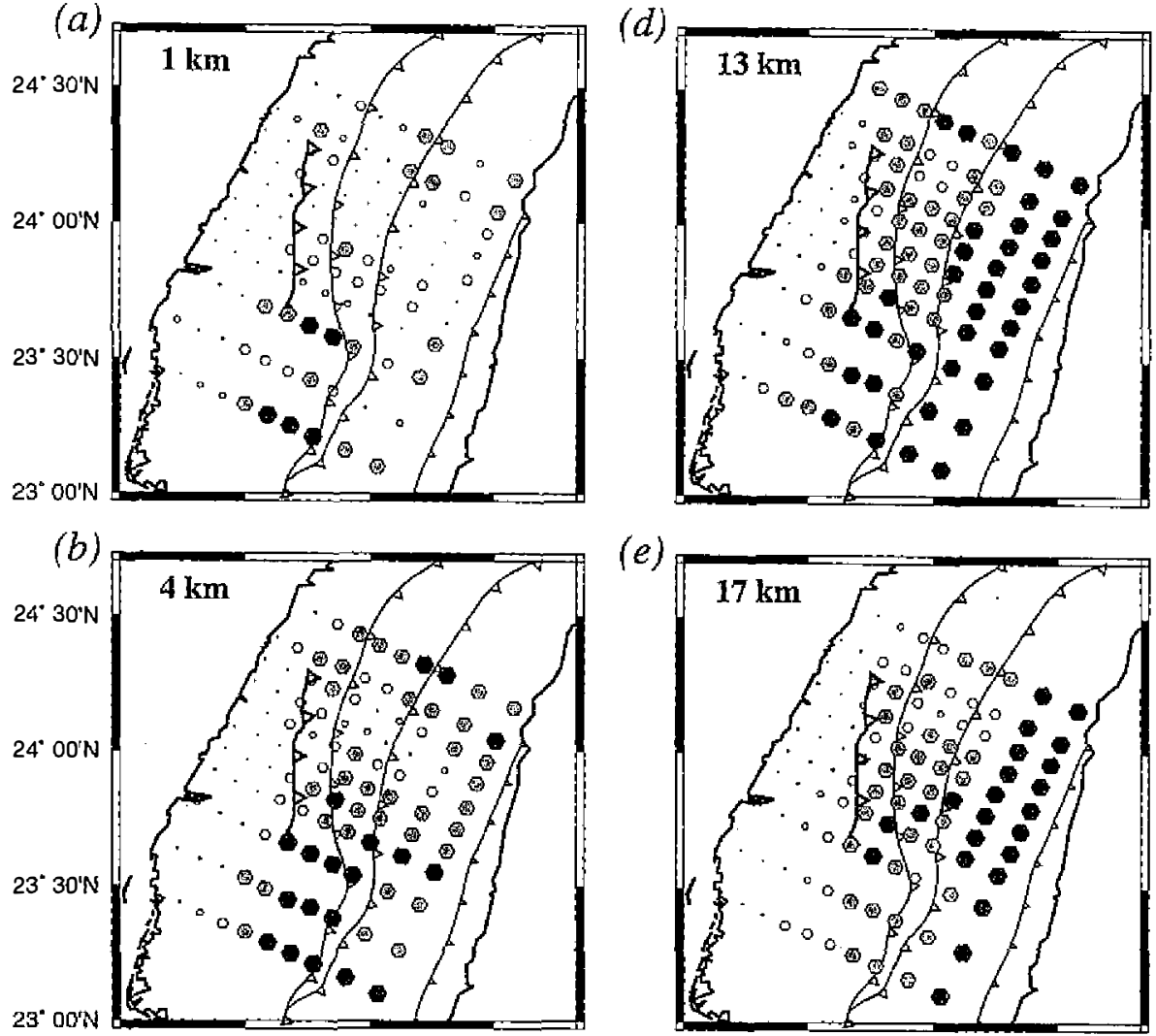

(e)
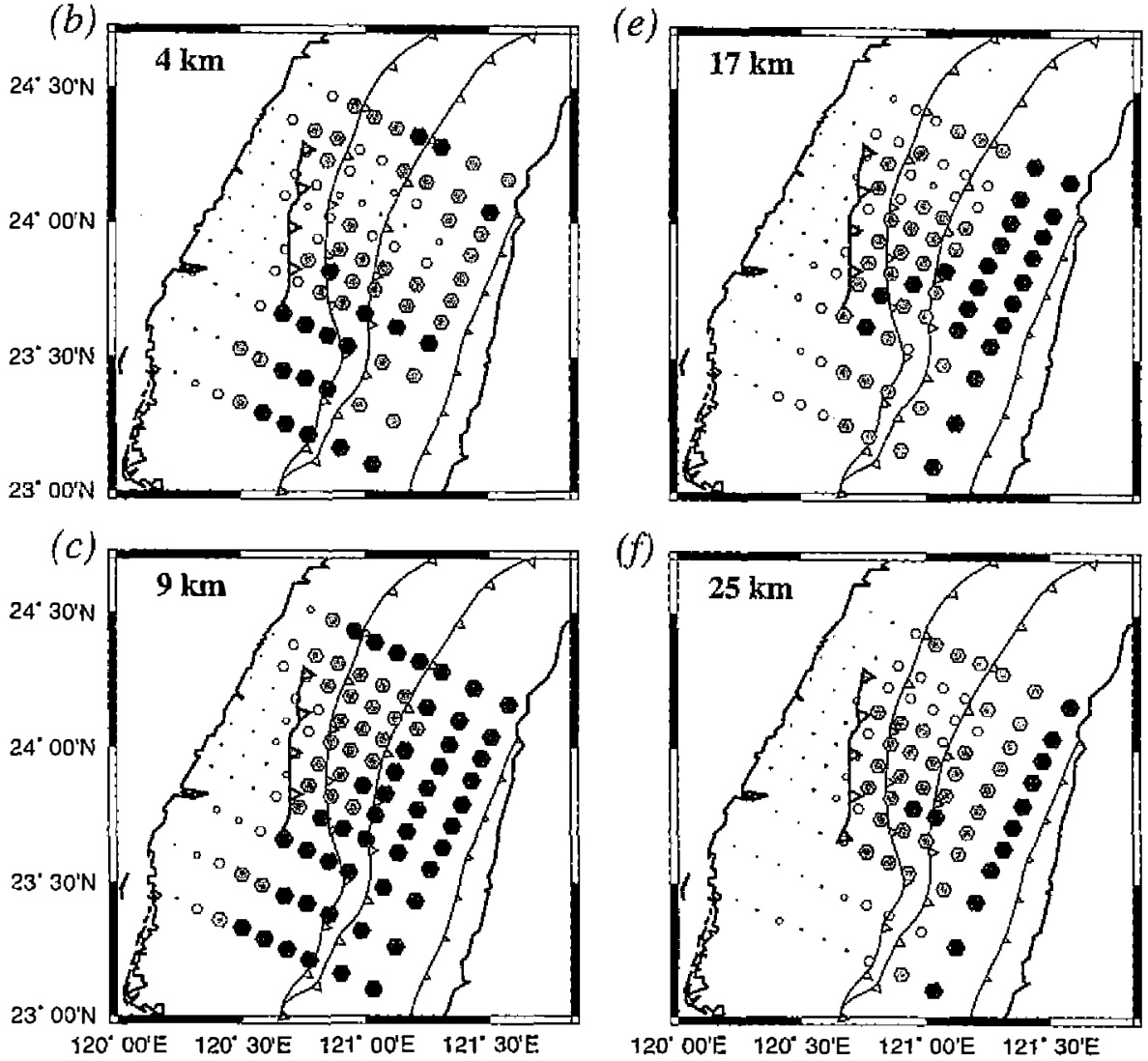

(f)

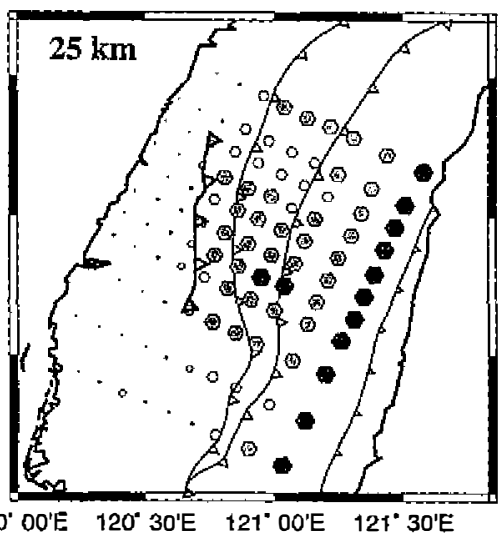

$0-0.1-0.25 \cdot 0.4-0.6 \cdot 0.8-1$

Fig. 4. Values of diagonal element of resolution matrix for velocity model at depths of (a) $1 \mathrm{~km}$; (b) $4 \mathrm{~km}$, (c) $9 \mathrm{~km}$, (d) $13 \mathrm{~km}$, (e) $17 \mathrm{~km}$, and (f) 25 $\mathrm{km}$. Larger values indicate that the velocity value is well resolved and spatially well constrained. 
zone in central Taiwan. From $z=1$ to $z=9 \mathrm{~km}$, the dominant feature in the velocity model is the relatively high $\mathrm{Vp}$ zone ranging from about 4.8 to $6.2 \mathrm{~km} / \mathrm{s}$ which is generally bound by the Chuchih fault in the west. There is a significant $\mathrm{N}$-S elongated high velocity volume distributed beneath the eastern flank of the Central Range and Longitudinal Valley shown at the 13$\mathrm{km}, 17-\mathrm{km}$ and $25-\mathrm{km}$ depth intervals. At $\mathrm{z}=17 \mathrm{~km}$, the velocity of this high $\mathrm{Vp}$ volume varies from 6.5 to $7.0 \mathrm{~km} / \mathrm{s}$ (Fig. 3e). The derivative weighted sum indicates high resolution for the high $\mathrm{Vp}$ feature. The other higher $\mathrm{Vp}$ feature is observed in the area west of the Chuchih fault from $13-\mathrm{km}$ to $25-\mathrm{km}$ depth intervals, and this might be associated with the Peikang basement high. Between these two middle crustal high-velocity volumes, the 3-D velocity model shows a large region of lower Vp beneath the Central Range and Westem foothills.

About 2,233 aftershocks of the Chi-Chi earthquake in Taiwan with magnitude $\geq 3$ were relocated with the obtained 3-D velocity model. The hypocenter part of the velocity-hypocenter inversion program (Thurber and Eberhart-Phillips 2000) was used to determine the 3-D locations. Figure 5 shows the relocated hypocenters and the hypocenters located by the CWB with a 1-D model. The rms residuals for the relocated hypocenters ranged from 0.01 to $0.4 \mathrm{~s}$ and are normally distributed with an average of $0.13 \mathrm{~s}$ and one standard deviation of $0.07 \mathrm{~s}$. The relocated hypocenters show a more clustered distribution than do the 1-D locations. The hypocentral depth changed from about an average of $10.8 \mathrm{~km}$ for 1-D locations to about 11.4 $\mathrm{km}$ for the 3-D locations.

Figures 6 and 7 show the 3-D velocity structure in a series of across-fault cross-sections and NE-SW sections. The locations of the vertical cross-sections shown in Figs. 6 and 7 are given in Fig. 5a. Aftershock and background earthquake hypocenters are projected horizontally onto the planes of the sections from about $5 \mathrm{~km}$ on either side. The most striking feature imaged by the 3-D velocity model is the high velocity wedge extending from surface to about a $15 \mathrm{~km}$ depth beneath the Western foothills, seen best in Fig. 6b. Lin et al. (1989) previously recognized a décollement-like seismic discontinuity at a depth of about $9 \mathrm{~km}$ in the SanyiFengyuan area using local earthquake data. On the other hand, an upper crustal high-velocity zone under the Central Range and a low velocity zone under the Western foothills had been imaged by Rau and $\mathrm{Wu}$ (1995).

Just west of the upper crustal high-velocity wedge, there is an uplift high velocity body in the middle crust where it is overlain with a basin-type low velocity material. In the eastern part of Fig. 6, the other prominent feature of the velocity model is the large velocity body beneath the eastern flank of the Central Range. The resolution is good (Fig. 4), showing that the pattern of the high velocity zone is realistic. However, the depth extent of the high-velocity body is not resolved, and it may extend deeper than allowed for in our model.

In the across-fault cross-sections, the relocated hypocenters of the Chi-Chi aftershocks show different patterns from south to north, as well as variable background seismicity (Fig. 6). Most of the aftershocks which occurred in these sections were generally concentrated beneath the region of the Western foothills. Based on surface ruptures and the inverted velocity model, the geometry of the sub-surface Chelungpu fault may be generally delineated (dashed line in Fig. 6b). However, they also show that the relationship between aftershock seismicity and the Chelungpu fault that we indicate is not quite so straightforward. There were triggered events beneath the Changhua plain (Fig. 6a) and the eastern flank of the Central Range (Fig. 6b) that 

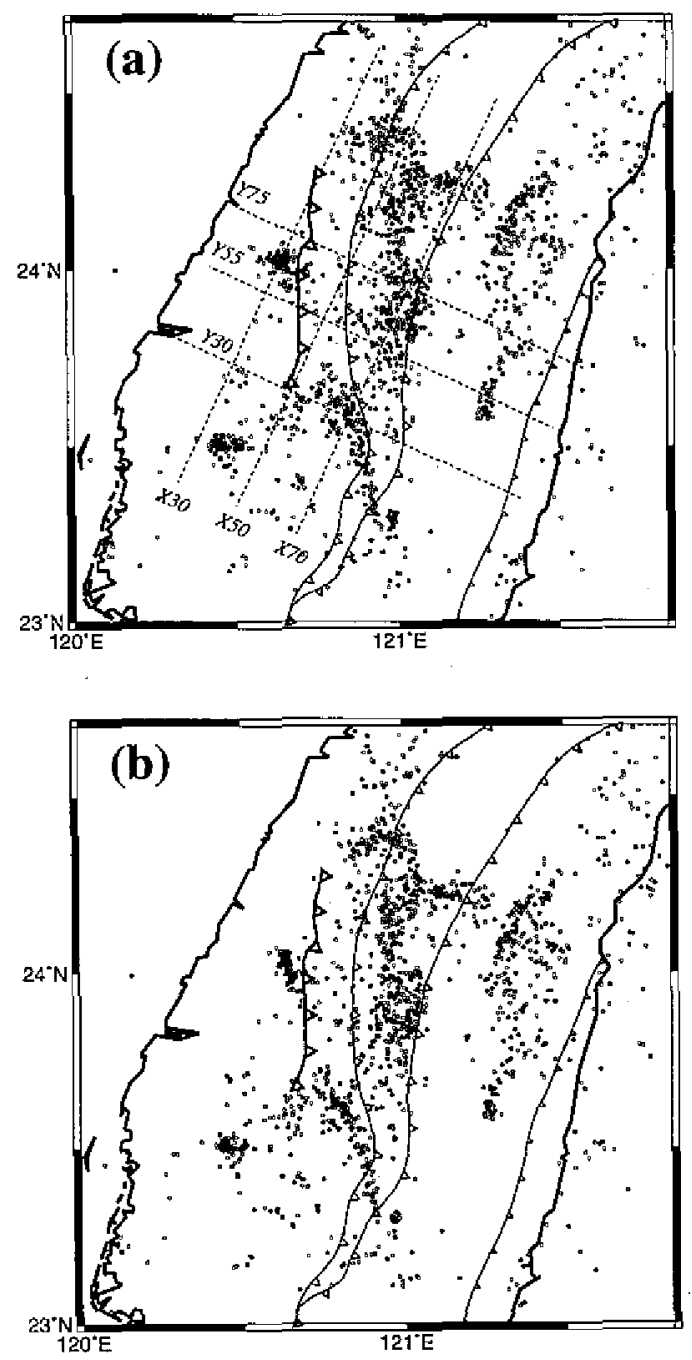

Fig. 5. (a) Hypocenters $(2,233)$ of the Chi-Chi, Taiwan earthquake located with the Central Weather Bureau one-dimensional velocity model. Lines X30, X50, $\mathrm{X} 70, \mathrm{Y} 30, \mathrm{Y} 55$ and $\mathrm{Y} 75$ denote the positions of the cross-sections shown in Figs. 6 and 7. (b) The same events were relocated with the three-dimensional velocity model developed in this paper. Note that the epicenters are concentrated when compared to the locations shown in (a)

were not directly associated with the Chi-Chi mainshock rupture area.

In the N-S cross-sections (Fig. 7), the hypocentral distribution of the Chi-Chi aftershocks was generally located within the low-velocity volumes, which is similar to that in the acrossfault cross-sections. However, it is significant that there were numerous events which formed clusters adjacent to the bodies of high velocity, as shown in Fig. 7.

\section{DISCUSSION}

\subsection{Relationship of Seismicity to Fault Zone Lithology}

Figure 6 shows the southern (Y30), central (Y55) and the northem (Y75) sections of the Chelungpu fault in central Taiwan. It shows that the characteristics of the seismicity varied 
(a) Y75

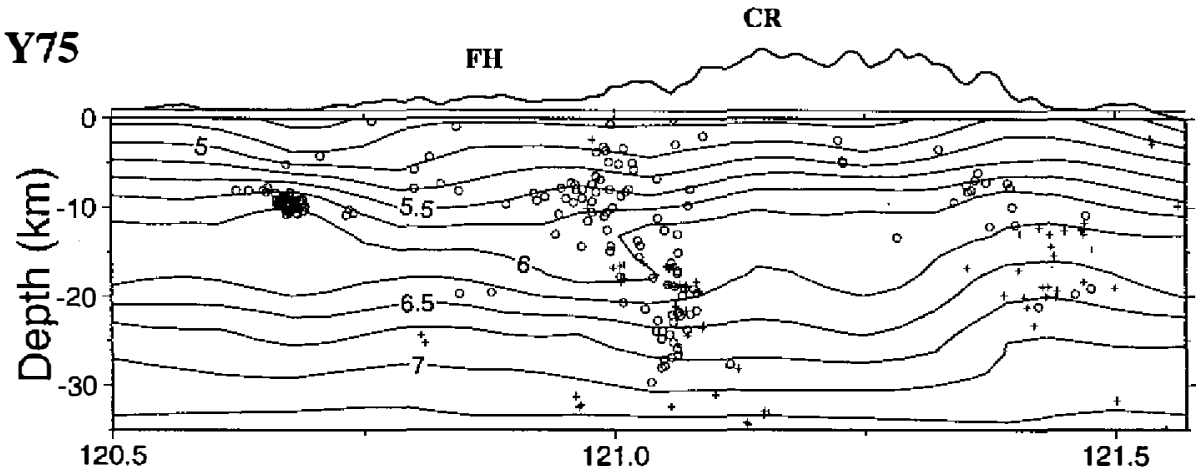

(b) Y55

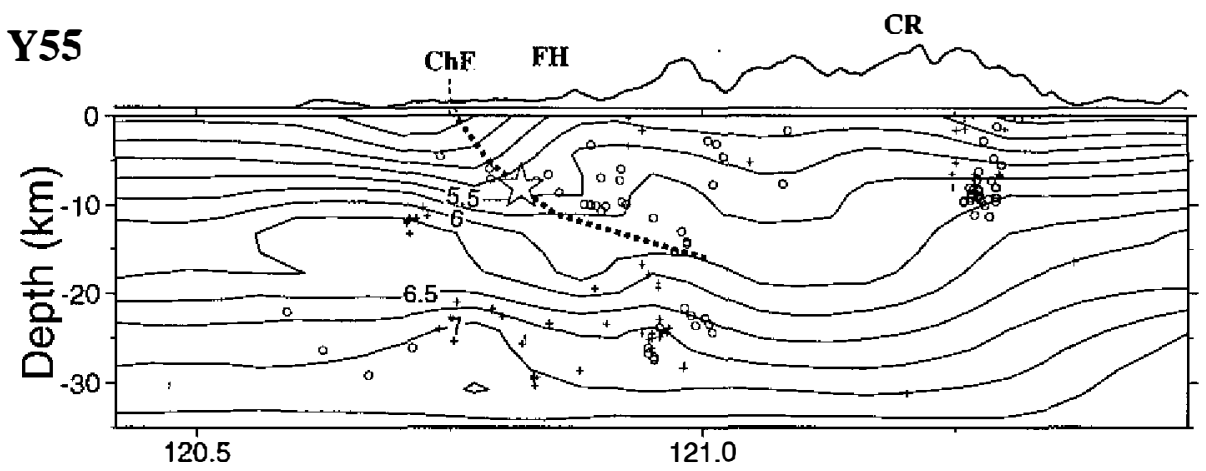

(c) Y30

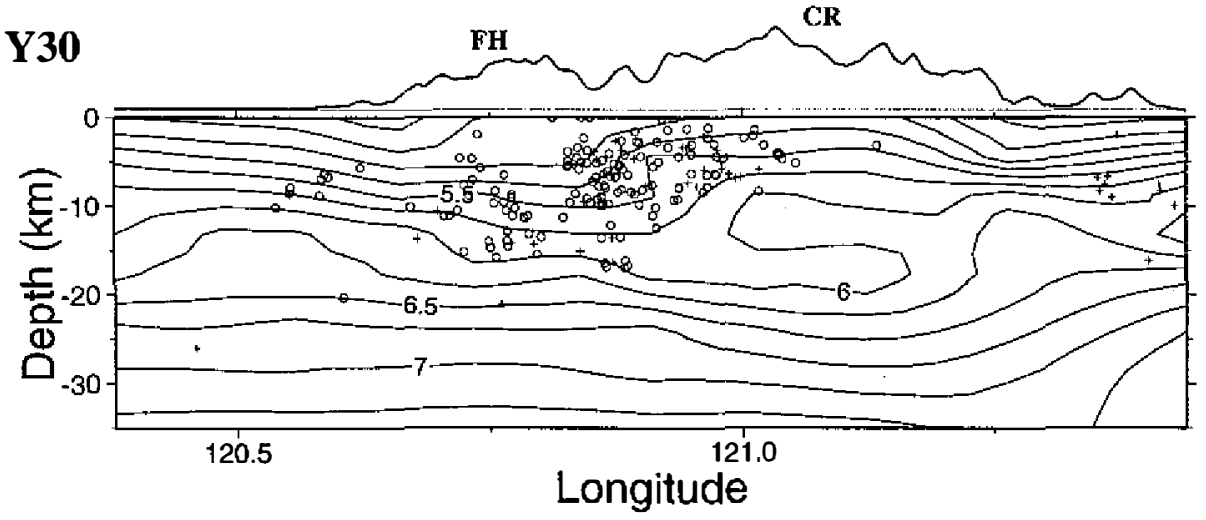

Fig. 6. Vertical cross-sections of the 3-D velocity structure contoured at $0.2 \mathrm{~km} /$ s intervals along the (a) Y75, (b) Y55 and (c) Y30 sections as shown in Fig. 5a. The topography of each cross-section is shown at the top. The inferred Chelungpu fault $(\mathrm{ChF})$ is sketched in with a dashed line in (b). Vertical exaggeration is 1:1. Hypocenters of the Chi-Chi aftershocks (open circles) and background earthquake (crosses) are projected horizontally onto the planes of the sections from about $5 \mathrm{~km}$ on either side. $\mathrm{CR}=$ Central Range; $\mathrm{FH}=$ Western foothills. 
(a) $\times 70$

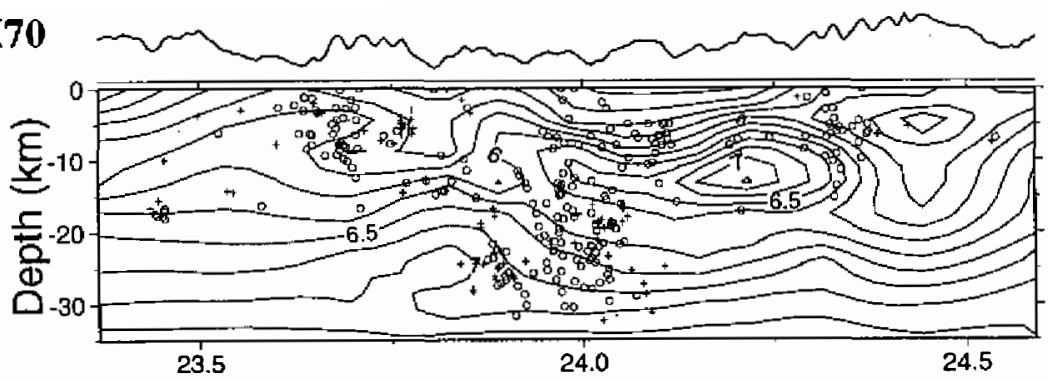

(b) $\mathrm{X50}$

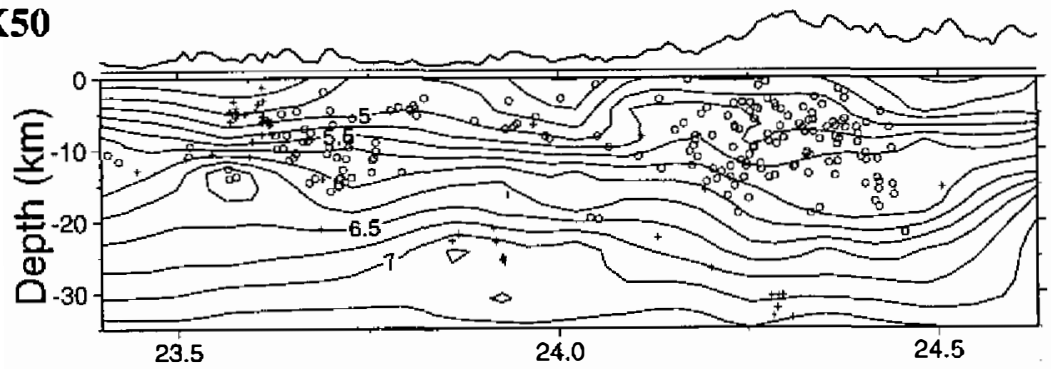

(c) $\mathrm{X30}$

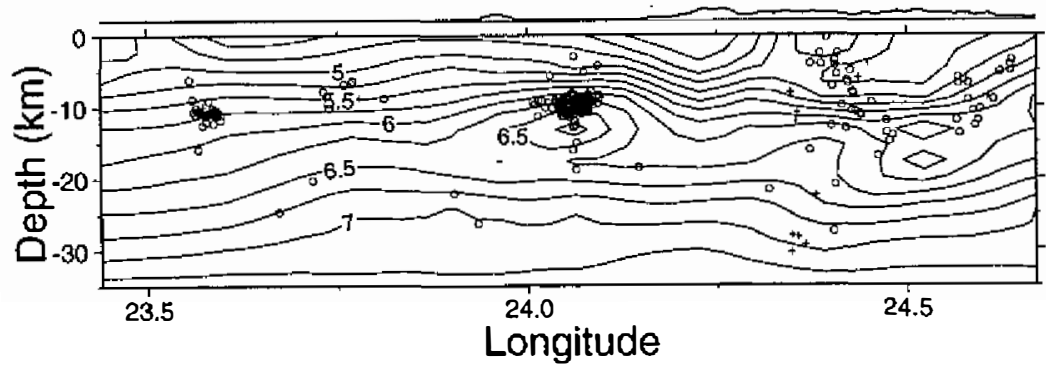

Fig. 7. Vertical cross-sections of the 3-D velocity stucture contoured at $0.2 \mathrm{~km} /$ s intervals along the (a) X70, (b) X50 and (c) X30 sections as shown in Fig. 5a. The topography of each cross-section is shown at the top. Hypocenters of the Chi-Chi aftershocks (open circles) and background earthquake (crosses) are projected horizontally onto the planes of the sections from about $5 \mathrm{~km}$ on either side (without vertical exaggeration).

with the degree of pre-mainshock deformation. The southern part showed a moderate amount of uplift, evidenced by the relatively wide Westem foothills and the adjoining Central Range. The aftershocks showed diffuse seismicity from 0 to $20 \mathrm{~km}$ depths (Fig. 6c). The central (mainshock) zone revealed the most recent deformation, including the development of a sharp upthrust structure below the Western foothills (Fig. 6b). The shallow seismicity also showed a distinct zone of back-thrust faulting below the eastern flank of the Central Range. The fault 
plane solutions (Chien-Hsin Chang, personal communication) showed normal mechanisms for those moderate earthquakes (Fig. 8a). The northern part showed the least deformation. On the other side, there was very little concentrated shallow seismicity below the Changhua plain from the 5- to 15-km depth (Fig. 6a).

From the distribution of the Chi-Chi aftershocks (Fig. 1b), it is obvious that most of the aftershocks occurred in the hanging wall east of the Chuchih fault, where the region between the Chelungpu fault and Chuchih fault is relatively quiescent. The area near the Chi-Chi mainshock that lacked aftershocks coincides with the area of greatest slip (Lee et al. 1999) during the mainshock. This is similar to the case of some other earthquake sequences where there was an absence of aftershock activity on the part of the rupture plane that suffered the maximum co-seismic displacement (e.g., Mendoza and Hartzell 1988).

In the velocity map views (Fig. 3), the near-surface low Vp features west of the Chuchih fault in the central Taiwan area coincide with the observation of sediment deposition shown in surficial geology (Ho 1986). Large Vp variations of up to $0.4 \mathrm{~km} / \mathrm{s}$ are imaged in a NW-SE trending, adjacent to the north $\left(121^{\circ} \mathrm{E}, 24.5^{\circ} \mathrm{N}\right)$ and south $\left(121^{\circ} \mathrm{E}, 23.5^{\circ} \mathrm{N}\right)$ ends of the Chelungpu fault in the study area (Fig. 3). Numerous studies (e.g., Ouyed et al. 1983; King and Yielding 1984; Eberhart-Phillips 1989) show that thrust earthquakes can have a range of structures indicated by their aftershocks and secondary faults. The aftershocks can occur in both the hanging wall and footwall and do not necessarily coincide with the mainshock rupture surface. This means that the extent of the rupture area of the Chi-Chi earthquake in Taiwan might have been limited due to the structural orientation of the Western foothills and the variations in material properties. The 3D velocity model also suggests that the variations in the material properties may have limited the expanse of the mainshock rupture and could have influenced the distribution of aftershocks.

\subsection{Thrust Wedge and Hanging Wall Deformation}

One of the goals of this study was to image structures such as the deformation of the hanging wall associated with blind thrust faults. As mentioned above, the sub-surface geometry of the Chelungpu fault could be characterized by distinct lateral velocity variations in the middle- and upper-crust below the Western foothills. This crustal scale fault zone might consist of a set of east dipping thrusts including the upthrust higher-velocity wedge (Figs. $6 \mathrm{~b}$ and 8). Most of the Chi-Chi aftershocks occurred within the high Vp volume, including two $M_{L}$ 6.8 aftershocks. From the locations and fault plane solutions of the two strong aftershocks (Fig. 8), it is evident that the aftershocks represent movement on a series of blind thrust faults located on the hanging wall. Furthermore, the velocity model and aftershock hypocenters could help us to image blind thrusts and to confine the extent of the deformation of the hanging wall. The $6.0 \mathrm{~km} / \mathrm{s}$ contour line and the distribution of aftershocks indicates that the extent of deformation might have extended to middle-crust.

Just west of the presumed fault plane of the Chelungpu fault, there are relatively lower velocity materials in the $3-\mathrm{D}$ velocity structure ranging from about the 10 - to $20-\mathrm{km}$ depth (Fig. 8a). This indicates that along with uplifting higher Vp material of the Western foothills, the thrust faulting also pushed down lower Vp material on the western side (Fig. 8b). 

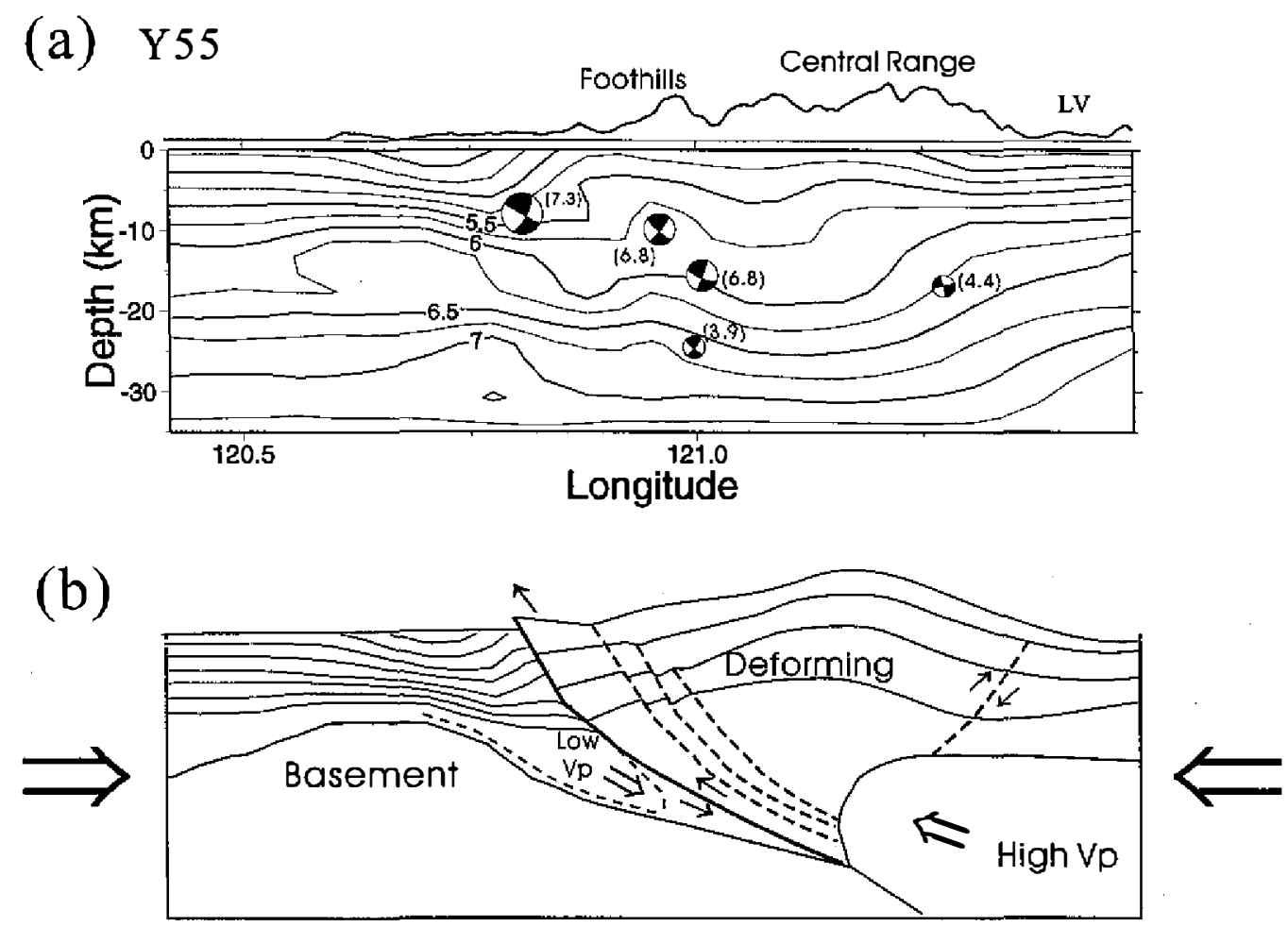

Fig. 8. (a) Vertical cross-sections of the 3-D velocity structure contoured at 0.2 $\mathrm{km} / \mathrm{s}$ intervals along the Y55 section shown in Fig. 5a. The inferred Chelungpu fault $(\mathrm{ChF})$ is sketched in with a solid line in $b$ (without vertical exaggeration). The focal mechanisms (large spheres, adapted from Chien-Hsin Chang, personal communication) of the mainshock and aftershocks provide information as to the blind thrust faults dashed lines in $\mathrm{b}$ and folding. The fault plane solutions are shown in equal-area projections of the back hemispheres of the focal sphere projected onto a plane perpendicular to the cross-section. LV = Longitudinal Valley. (b) Sketch drawing of a schematic cross-sectional view of the thrusting and deformation indicated by the velocity structure. Responding to regional compression, the Luzon forearc oceanic crust pushes the middle crustal material upward in front of the Peikang basement high. The material of the uplifting wedge deforms by folding and fracturing along a series of eastdipping blind thrust faults.

\subsection{Central Taiwan Tectonics}

Beyond the rugged topography and general seismicity, there are several specific indications that central Taiwan is a complex region. The broad Pakua anticline is growing up through 
the alluvium with a thrust fault on its western flank (Tang 1968). A number of the outermost thrusts in this area cut the late Pleistocene lateritic and Quatemary basin (e.g., Lee et al. 1996). This is also the region of the magnitude 7.2, Hsinchu-Taichung earthquake (Cheng and Yeh 1989) which had a surface rupture of approximately $50 \mathrm{~km}$. Furthermore, most of the Chi-Chi aftershocks did not occur at the boundary between the Quaternary basin and Western foothills but rather inside the latter (Fig. 1).

Beneath the eastern flank of the Central Range, a prominent high-velocity anomaly in the middle- to lower-crust is found (Figs. 3 and 6). Cheng et al. $(1998 ; 1999)$ proposed that the high velocity anomaly could be interpreted as trapped Luzon forearc oceanic crust. Another relatively high velocity anomaly is located west of the Chelungpu fault at midcrustal depths (Fig. 6), and should be associated with the Peikang basement high. The sedimentary Changhua plain, coincides with the basin type of low Vp materials above the Peikang basement high. Between these two high velocity volumes, the 3-D velocity model reveals a broad low Vp zone in the middle-crust under the Central Range and Western foothills. Figure 6 shows that the Central Range is an earthquake quiescent zone even after the Chi-Chi mainshock. It has been proposed that the nature of the crustal composition of the Central Range might be ductile (e.g., Wu et al. 1997) or elevated heat flow (e.g., Ma et al. 1996). It deforms and uplifts in response to regional compression. On the other hand, the Western foothills, composed of layered Miocene to early Pleistocene sandstone and shale intercalation sediments, might be a large region of high pore pressure, which could influence rupturenucleation (Sleep and Blanpied 1992). As the rupture fractures into a volume of high pore pressure under regional compression, the fluid pressure might suddenly be reduced, thus causing an instantaneous change in the material properties of the Western foothill fault zones.

Although the role of the tectonic extrution affecting the front zone of the fold-and-thrust belt around the Peikang basement high has previously been studied using physical and numerical modeling (Lu, 1994; Lu and Malavieille 1994; Hu et al. 1997), in this study, a simple model is proposed for central Taiwan tectonics based on the 3-D velocity model along the across-fault direction (Fig. 8b). It is suggested that the eastern Taiwan forearc oceanic crust pushes a high-velocity wedge of the active Western foothills upward in front of the relatively rigid Peikang basement high in response to regional compression.

\section{CONCLUSIONS}

This study has demonstrated the utility of three-dimensional seismic tomography in investigating the velocity structure around the source area of the 1999 Chi-Chi earthquake in Taiwan in order to get the picture of the faulting and deformation prior to the mainshock. In particular, this paper has illustrated the influence that crustal scale lithological heterogeneity may have on the Western foothill fault zones and the Chi-Chi aftershock distribution.

The sub-surface Chelungpu fault can be interpreted with an obvious lateral velocity variation that marks a transition from sedimentary material of the Chunghua plain to the Neogene rocks of the Western foothills from surface to middle-crust below the Western foothills. East of the Chelungpu fault, the fractured structure beneath the Western foothills might consist of 
southeast dipping blind thrusts inside an uplifting wedge of higher-velocity material.

The application of this method to the pre-mainshock "background" earthquakes has enabled us to image a large anomalous high velocity volume in the middle-to lower-crustal depths beneath the eastern flank of the Central Range. Another middle-crust high velocity volume located west of the Chelungpu fault could be associated with the Peikang basement high. Between these two high-velocity volumes, the velocity model shows a large region of relatively low velocity underlying the Central Range and Western foothills. On the basis of the relationship between the velocity model, the relocated seismicity and surface geology, the thrust faulting and deformation that resulted from the 1999 Chi-Chi, Taiwan earthquake could be interpreted as the interactions between the high-low-high velocity volumes.

Acknowledgments The author would like to express his appreciation to the Seismological Observation Center, Central Weather Bureau, for providing the earthquake data. Appreciation is also due to Drs. C. Wang, H. T. Chu, C. S. Lee and B. Y. Kuo for their valuable discussions. The anonymous reviewers have greatly improved the manuscript. The research was supported by the National Science Council of the Republic of China, under grant NSC 89-2116-M-052001.

\section{REFERENCES}

Chai, B. H. T., 1972: Structure and tectonic evolution of Taiwan. Am. J. Sci., 272, 289-442.

Cheng, S. N., and Y. T. Yeh, 1989: Catalog of the earthquakes in Taiwan from 1906 to 1988. Inst. Earth Sci., Academia Sinica, IES-R-661, 255pp.

Cheng, W. B., C. Wang, C. T. Shyu, and T. C. Shin, 1998: A three-dimensional Vp model of the southeastern Taiwan area and its tectonic implications. TAO, 9, 425-452.

Cheng, W. B., C. Wang, C. T. Shyu, and T. C. Shin, 1999: Crustal structure of the convergent plate-boundary zone, eastern Taiwan, assessed by seismic tomography. Geol. Soc. Am. Bull., (revised)

Chou, J. T., 1973: Sedimentary and paleogeography of the upper Cenozoic system of western Taiwan. Pet. Geol. Taiwan, 16, 111-143.

Covey, M., 1986: The evolution of foreland basins to steady state: evidence from the western Taiwan foreland basin. In: P.A. Allen and P. Homewood (Eds.), Foreland Basins. Int. Assoc. Sedimentol. Spec. Publ., 8, 77-90.

Eberhart-Phillips, D., 1986: Three-dimensional velocity structure in northern California Coast Ranges from inversion of local earthquake arrival times. Bull. Seism. Soc. Am., 76, 1025-1052.

Eberhart-Phillips, D., 1989: Active faulting and deformation of the Coalinga anticline as interpreted from three-dimensional velocity structure and seismicity. J. Geophys. Res., 94, 15565-15586.

Eberhart-Phillips, D., 1990: Three-dimensional P and S velocity structure in the Coalinga region, California. J. Geophys. Res., 95, 15343-15363.

Eberhart-Phillips, D., and A. Michael, 1993: Three-dimensional velocity structure, seismicity, and fault structure in the Parkfield region, central California. J. Geophys. Res., 98, 
$15737-15758$.

Evans, J. R., Eberhart-Phillips, D., and Thurber, C. H., 1994: User's manual for SIMULPS 12 for imaging $\mathrm{Vp}$ and $\mathrm{Vp} / \mathrm{Vs}$ : A derivative of the "Thurber" tomographic inversion SIMUL3 for local earthquake and explosions. U.S. Geol. Surv. Open File Rep., 94431.

Ho, C. S., 1982: Tectonic Evolution of Taiwan. Explanatory Text of the Tectonic Map of Taiwan. Minist. of Econ. Affairs, Taipei, $126 \mathrm{pp}$.

Ho, C. S., 1986: A synthesis of the geologic evolution of Taiwan. Tectonophysics, 125, 1-16.

Ho, C. S., 1988: An introduction to the geology of Taiwan: Explanatory text for the geologic map of Taiwan. Minist. of Econ. Aff. Taipei, $2^{\text {nd }}$ ed., 164 pp.

Hu, J. C., J. Angelier, and S. B. Yu, 1997: An interpretation of the active deformation of southern Taiwan based on numerical simulation and GPS studies. Tectonophysics, 274, 145-169.

Hsu, S. K., C. S. Liu, C. T. Shyu, S. Y. Liu, J. Sibuet, S. Lallemand, C. Wang, and D. Reed, 1998: New gravity and magnetic anomaly maps of the Taiwan-Luzon region and their preliminary interpretation. TAO, 9, 509-532.

Johnson, P. A., and T. V. McEvilly, 1995: Parkfield seismicity: Fluid-driven?. J. Geophys. Res., 100, 12937-12950.

King, G., and G. Yielding, 1984: The evolution of a thrust fault system: Processes of rupture initiation, propagation and termination in the $1980 \mathrm{El}$ Asnam (Algeria) earthquake. Geophys. J. R. Astron. Soc., 77, 915-933.

Lee, J. C., C. Y. Lu, H. T. Chu, B. Delcaillau, J. Angelier, and B. Deffontaines, 1996: Active deformation and paleostress analysis in the Pakua anticline area of western Taiwan. $T A O, 7,431-446$.

Lee, J. F., J. H. Hou, C. C. Lin, and T. C. Lai, 1999: Chelungpu fault and the Chi-Chi, Taiwan earthquake. Conference on the 1999 Chi-Chi, Taiwan earthquake, Central Weather Bureau, 7-36.

Lees, J. M., and C. E. Nicholson, 1993: Three-dimensional tomography of the 1992 southern California earthquake sequence: Constraints on dynamic earthquake rupture?. Geology, 21, 387-390.

Lin, C. H., Y. H. Yeh, and S. W. Roecker, 1993: Seismic velocity structures in the SanyiFengyuan area, central Taiwan. Proc. Geol. Soc. China, 32, 101-120.

Lu, C. Y., 1994: Neotectonics in the foreland thrust belt of Taiwan. Pet. Geol. Taiwan, 29, 126.

Lu, C. Y., and J. Malavielle, 1994: Oblique convergence, indentation and rotation tectonics in the Taiwan mountain belt: insights from experimental modeling. Earth Planet. Sci. Lett., 121, 477-494.

Ma, K. -F., J. -H.Wang, and D. Zhao, 1996: 3-D seismic structure of the crust and uppermost mantle beneath Taiwan. J. Phys. Earth, 44, 85-105.

Mendoza, C., and S. H. Hartzell, 1988: Aftershock patterns and mainshock faulting. Bull. Seism. Soc. Am., 78, 1438-1449.

Ouyed, M., G. Yielding, D. Hatzfield, and C. P. King, 1983: An aftershock study of the El Asnam (Algeria) earthquake of 1980 October 10. Geophys. J. R. Astron. Soc., 73, 605- 
639.

Pavlis, G. L. and J. R: Booker, 1980: The mixed discrete-continuous inverse problem: Application to the simultaneous determination of earthquake hypocenters and velocity structure. J. Geophys. Res., 85, 4801-4810.

Shin, T. C., 1993: The calculation of local magnitude from the simulated Wood-Anderson seismograms of the short-period seismograms in the Taiwan area. TAO, 4, 155-170.

Sleep, N. H., and M. L. Blanpied, 1992: Creep, compaction and the weak rheology of major faults. Nature, 359, 687-692.

Sun, S. C., 1985: The Cenozoic tectonic evolution of offshore Taiwan. Energy, 10, 421-432.

Tang, C. H., 1968: Photogeological observations on the low hilly terrain and coastal plain area of Hsinchu, Taiwan. Petrol. Geol. Taiwan, 6, 71-79.

Thurber, C. H., 1983: Earthquake locations and three-dimensional crustal structure in the Coyote Lake area, central California. J. Geophys. Res., 88, 8226-8236.

Thurber, C. H., 1993: Local earthquake tomography: Velocities and Vp/Vs - Theory, in Seismic Tomography: Theory and Practice. In: H. M. Iyer and Hirahara (Eds.), Chapman and Hall, New York, 563-583.

Thurber, C., S. Roecker, W. Ellsworth, Y. Chen, W. Lutter, and R. Ressions, 1997: Twodimensional seismic image of the San Andreas Fault in the Northern Gabilan Range, central California: evidence for fluids in the fault zone. Geophys. Res. Lett., 24, 15911594.

Thurber, C., and D. Eberhart-Phillips, 2000: Local earthquake tomography with flexible gridding. Computer \& Geosciences, 25, 809-818.

Um, L. and C. H. Thurber, 1987: A fast algorithm for two-point seismic ray tracing. Bull. Seism. Soc. Am., 77, 972-986.

Wu, F. T., R. J. Rau, and D. Salzberg, 1997: Taiwan orogeny: thin-skinned or lithospheric collision? Tectonophysics, 274, 191-220.

Wu, Y. M., T. C. Shin, C. C. Chen, Y. B. Tsai, W. H. K. Lee, and T. L. Teng, 1997: Taiwan rapid earthquake information release system. Seismol. Res. Lett., 68, 931-943

Yu, S. -B., H. -Y. Chen, and L. -C. Kuo, 1997: Velocity field of GPS stations in the Taiwan area. Tectonophysics, 274, 41-59.

Zhao, D., 1998: Seeking the cause of earthquakes. Science Spectra, 11, 6-10.

Zhao, D., and H. Kanamori, 1995: The 1994 Northridge earthquake: 3-D crustal structure in the rupture zone and its relation to the aftershock locations and mechanisms. Geophys. Res. Lett, 22, 763-766.

Zhao, D., and H. Negishi, 1998: The 1995 Kobe earthquake: seismic image of the source area and its implications for the rupture nucleation. J. Geophys. Res., 103, 9967-9986. 